\title{
Selective predation by fish: a further reason for the decline of native gammarids in the presence of invasives?
}

\author{
Werner KINZLER and Gerhard MAIER* \\ Department of Experimental Ecology of Animals (Biology III), University of Ulm, Albert-Einstein-Allee 11, 89069 Ulm, Germany \\ *e-mail corresponding author: gmaier.limnos@t-online.de
}

\begin{abstract}
Predation by fish (rainbow trout and perch) on the invasive gammarids Dikerogammarus villosus and Echinogammarus ischnus and the natives Gammarus fossarum, Gammarus roeseli and Gammarus pulex was investigated under different substrate conditions (gravel, large stones, fine sand) in laboratory experiments. Gravel and stones (coarse substrates) should provide refuge for gammarids while sand (fine substrate) should offer little refuge. One additional set of experiments was run without any substrate to investigate the risk of gammarids to fish predation in the absence of any refuge. When, in mixed-prey experiments, combinations of native and invasive species were exposed to fish predation, fish (both trout and perch) ate many more native gammarids than invasives under conditions of coarse substrate. However, fish (trout) ate the same quantity of native and invasive gammarids under conditions of fine substrate but relatively more of the invasive D. villosus when no substrate was present. Single-prey experiments, which were conducted under conditions of stony substrate, supported the results of the mixed prey experiments in that the native $\mathrm{G}$. pulex was eaten by fish somewhat more frequently than the invasives $\mathrm{D}$. villosus and $\mathrm{E}$. ischnus. However, the native $\mathrm{G}$. roeseli was eaten as frequently by fish as were the invasives. Further experiments, where substrate affinity and activity of gammarids was tested, showed that invasive species were less active than natives and that invasives (in particular D. villosus) displayed a high affinity to coarse substrate. The results suggest that when native and invasive gammarids co-exist in rivers where gravelly or stony bottom sediments prevail, native species suffer higher losses due to fish predation than the invasives. In rivers with sandy sediment the advantage of low predation risk for the invaders vanishes. The results further suggest that the high predation risk of natives originates from their high activity and that differences in predation risk between native and invasive gammarids during their coexistence may have contributed to the decline of natives in large rivers of Southern Germany.
\end{abstract}

Key words: invasive / native gammarids, fish predation, substrate, activity, substrate affinity

\section{INTRODUCTION}

The invasion of ecosystems by non-indigenous species is commonplace in nature. The extent of this invasion, however, has been driven by human activity that has increased dramatically over the last decades (e.g. Schöll et al. 1995; Schöll 1996; Tittizer 1996). Thus the problem of biological invasion has become an important topic in biodiversity research and a significant form of global change (Lodge 1993, Kinzelbach 1995, Ricciardi et al. 2000). In freshwater ecosystems humans have significantly aided the spread of species beyond their normal range. About $15 \%$ of the macrozoobenthic fauna of large Central European streams are believed to be non-indigenous (Kinzelbach 1995). This estimate is probably too low because the invasion of very small species, which are difficult to determine, are likely to go undetected. Building canals which connect large rivers, intensifying shipping traffic, increasing pollution, and destroying natural structures have all promoted the expansion of exotics (Lodge 1993; Kinzelbach 1995).

Many rivers in Central Europe have been invaded by gammarids from the Mediterranean and/or PontoCaspian region (e.g. Tittizer 1996, Tittizer et al. 2000). In some parts of the rivers Rhine, Danube and Main, native gammarids have been completely displaced by invasives (Kley \& Maier 2003). The mechanisms by which this species displacement took place are complex and insufficiently known. Several authors (e.g. Dick 1992, 1995; Dick et al. 1993; Dick \& Platvoet 2000; Kinzler \& Maier 2003) have shown that invasive gammarids can be aggressive predators and prey heavily on native gammarids. Aggression by invasives can alter the behaviour of natives, and possibly force natives to leave refugia and become more vulnerable to vertebrate predation.

In this paper we measured the risk of native and invasive gammarids to fish predation. Low predation pressure on invasive species in their novel habitat is frequently regarded as fundamental to their success and proliferation (Crawley 1987; Wells \& Henderson 1993; Trowbridge 1995; MacNeil et al. 2000). We suspected that, due to possible changes in behaviour (see above), native gammarids were more frequently eaten by fish than were invasives. If native species were selected by fish in the presence of invasives, this selective feeding could have contributed to their decline in Central European Rivers. We examined the effects of fish predation on gammarids under different substrate conditions. Substrate offers shelter for gammarids (e.g. Hoyle \& Holomuzki 1990; Starry et al. 1998). Thus the composition of the substrate determines the amount of 
refugia and thereby can determine the outcome of predator-prey interactions (Williams \& Moore 1982; Byers 2000, 2002).

\section{METHODS}

\subsection{Collection and treatment before the experiments}

Five gammarid species were used in our experiments. Dikerogammarus villosus (SOVINSKY) and Echinogammarus ischnus (STEBBING) are nonindigenous, invasive species which originate from the Ponto-Caspian region. Both species invaded Central European large rivers (Rhine, Main and Danube) in the 1990 s, have displaced natives in the last decade, and are now the prevailing species (Schöll et al. 1995; Schöll 1996; Tittizer 1996; Weinzierl et al. 1996; Grabow et al. 1998; Kley \& Maier 2003). Gammarus pulex (L.), Gammarus roeseli (GERVAIS) and Gammarus fossarum (KOCH) are very common native species. Gammarus pulex and G. roeseli prevailed in Central European large rivers until the late 1980s; G. fossarum was also present in large rivers but is much more frequent in the upper reaches of tributaries. Dikerogammarus villosus is the largest of the test species with a mean wet weight of 80 and $50 \mathrm{mg}$ in males and females, respectively. Echinogammarus ischnus and $G$. roeseli are of intermediate size (mean wet weight males 45 , females $25-37 \mathrm{mg}$ ) while G. fossarum and G. pulex are the smallest species (wet weight males 30, females $25 \mathrm{mg}$ ). The invasive species were collected at two sites in the River Main, near the town of Würzburg $\left(49^{\circ} 51.5^{\prime} \mathrm{N}, 10^{\circ} 12^{\prime} \mathrm{E}\right.$ and $49^{\circ} 52.5^{\prime} \mathrm{N}, 9^{\circ} 51^{\prime} \mathrm{E}$, respectively). Both species live sympatrically there and are the only gammarid species at these sites. The native species originates from the rivers Brenz $\left(48^{\circ} 37^{\prime} \mathrm{N}, 10^{\circ} 09^{\prime} \mathrm{E} ; G\right.$. fossarum $)$ and Danube $\left(48^{\circ} 25^{\prime} \mathrm{N}, 10^{\circ} 02^{\prime} \mathrm{E}\right.$; G. pulex and $G$. roeseli). The substrate at the 4 sites is mainly composed of gravel and large stones. Submerged macrophytes are only present in the Brenz. The sites can be characterized as "summer warm" (maximum temperature $>20^{\circ} \mathrm{C}$ ) with a low current velocity in near-shore areas $\left(<0.02 \mathrm{~m} \mathrm{~s}^{-1}\right)$ and hard (total hardness between 5 and $7 \mathrm{meq}^{-1}$ ) nutrient rich (soluble phosphorus $>40 \mu \mathrm{g}$ $1^{-1}$ ) water. More details concerning water quality are given elsewhere (Lutz 1997; Kley \& Maier 2003).

Prior to the experiments all gammarids were kept at natural densities (200-600 ind. $\mathrm{m}^{-2}$; Kley 2001) in aerated aquaria $(40 \times 25 \times 25 \mathrm{~cm})$, supplied with substrate (gravel with a grain size of $0.5-2 \mathrm{~cm}$ ) and leaves (mainly Salix alba) from the rivers. All aquaria were placed in a temperature chamber. Maintenance temperature was $18^{\circ} \mathrm{C}\left( \pm 0.5^{\circ} \mathrm{C}\right)$, the light regime was 16:8 hrs light:dark and approximately $5 \mathrm{~W} \mathrm{~m}^{-2}$. Light was provided by Osram cool white fluorescent lamps. The temperature, light:dark regime corresponds to conditions in summer in the field. A gentle flow (approximately $0.03 \mathrm{~m} \mathrm{~s}^{-1}$ ), consistent with that observed at the sites where gammarids were collected (Kley \&
Maier 2003), was provided by aquarium pumps. During their maintenance all gammarids were kept in aged tap water. Under these conditions gammarids could be maintained for weeks.

Rainbow trout (Oncorhynchus mykiss, WALBAUM) and perch (Perca fluviatilis L.) of a body size of $12 \mathrm{~cm}$ were obtained from a fish farm (Böck, Oberkochen) and from the river Wörnitz, respectively. These species were used because they are common in Central European rivers and present in the rivers Main and Danube (e.g. Lelek 1996) where gammarids were collected. Trout is a drift-feeding predator but can shift to bottom foraging when drift densities are low, whereas perch is predominantly a bottom-feeder (Bisson 1978; Dahl 1998). Gammarids are known to be a food source for both trout and perch (Bisson 1978; Newman \& Waters 1984; Williams \& Moore 1985). The fish were kept in $275 \mathrm{~L}$ aquaria $(110 \times 50 \times 50 \mathrm{~cm})$ filled with aged tap water and supplied with gravel $(0.5-2 \mathrm{~cm}$ diameter) as substrate. They experienced the same temperature and light conditions as the gammarids. During an acclimatization period of at least one month the fish were fed mainly with a mixture of invasive and native gammarids. Similar acclimatization periods were used in earlier experiments (cf. MacNeil et al. 2000).

\subsection{Mixed prey experiments}

The experiments were conducted in $120 \mathrm{~L}$ aquaria $(100 \times 35 \times 35 \mathrm{~cm})$. Temperature and light were as described above. The aquaria were supplied with either sand (grain size 1-2 mm), gravel (grain size 1-2 cm) or large stones (size approximately $10 \mathrm{~cm}$ ). Gravel and stones were regarded as substrates which offer refuge for gammarids while sand was regarded as substrate which offers little refuge (cf. Williams \& Moore 1982). Sand and gravel were introduced to a depth of $4-5 \mathrm{~cm}$. In the experiments with stones, 5 stones (no other substrate) were evenly distributed at the bottom of the aquaria. One additional set of experiments was run without substrate. This experiment should show feeding of fish in the absence of any refuge.

Thirty adult individuals of a non-indigenous gammarid species and 30 of a native species were taken from the stock cultures and introduced into an aquarium. The final density (60 gammarids per aquarium, i.e. 180 ind. $\mathrm{m}^{-2}$ ) corresponded well with natural densities observed at the sampling sites in the River Main (Kley 2001). We selected the largest individuals of native gammarids (total length of natives: 9-12 $\mathrm{mm}$ ) and smaller adults of invasives (total length of $D$. villosus: 11-15 mm; total length of E. ischnus: $10-13 \mathrm{~mm}$ ) to reduce possible effects of size on fish feeding behaviour. After an acclimatization time of $15 \mathrm{~min}$. which proved to be sufficient for gammarids to seek shelter in the substrate (Starry et al. 1998; MacNeil et al. 2000, this study), one fish which had been deprived of food for $48 \mathrm{hrs}$ was introduced and allowed to feed on the 
Tab. 1. Summary of predator-prey experiments. Dv, Ei, Gf, Gp, Gr are abbreviations for Dikerogammarus villosus, Echinogammarus ischnus, Gammarus fossarum, Gammarus pulex and Gammarus roeseli, respectively.

\begin{tabular}{ccccc}
\hline Experiment & Predator & Prey & Substrate & $\mathrm{N}^{\circ}$ trials \\
\hline Mixed prey & trout & $\mathrm{Dv} v s \mathrm{Gr}$ & gravel, stones, sand, no substrate & 40 \\
& & $\mathrm{Dv} v s \mathrm{Gf}$ & gravel, stones, sand, no substrate & 40 \\
& & Ei $v s \mathrm{Gr}$ & gravel, sand stones, no substrate & 40 \\
& & Ei $v s \mathrm{Gf}$ & gravel, sand stones, no substrate & 40 \\
& perch & Dv $v s \mathrm{Gp}$ & stones & 10 \\
& & Dv $v s \mathrm{Gf}$ & stones & 10 \\
Single prey & Ei $s$ Gp & stones & 10 \\
& trout & Dv, Ei, Gp, Gr & stones & 40 \\
& & & & 30 \\
\hline
\end{tabular}

gammarids for $60 \mathrm{~min}$. Preliminary experiments showed that between 15 and $60 \%$ of the gammarids had been consumed by the fish after that time. At the end of an experiment the fish was removed, and the aquarium (in particular the substrate) was carefully searched for gammarids and the survivors were counted. Different gammarid combinations were tested (Tab. 1). Trout experiments were conducted with all substrates and under non-substrate conditions; perch experiments were run with stones as substrate. In total 190 experiments (10 with each gammarid combination and each substratum) were carried out.

\subsection{Single prey experiments}

Single prey experiments were performed to test whether vulnerability to fish predation differed between the gammarid species in the absence of a heterospecific. Thirty individuals of a species were taken randomly from stock cultures and introduced into an aquarium which contained 10 large stones as substratum. After 15 min., during which gammarids could hide (see mixed prey experiments), one fish was added and allowed to feed on the gammarids for $60 \mathrm{~min}$. At the end of this time the fish was removed and the aquarium searched for survivors. Size of the aquarium, experimental conditions and treatment of gammarids and fish was as in the mixed prey experiments. The fish and gammarids used in the experiments are summarized in table 1 . In total 70 experiments (10 per species) were carried out.

\subsection{Substrate affinity, activity}

In a separate set of experiments the affinity of native and invasive gammarids to the coarse substrate (and their activity) was tested using stones (diameter $10 \mathrm{~cm}$ ) as substrate. The experiments were performed in small aquaria $(30 \times 20 \times 20 \mathrm{~cm})$ supplied with one stone. Ten native and 10 non-indigenous gammarids were introduced into each aquarium and the aquaria were observed over a period of $30 \mathrm{~min}$. The number of the gammarids sitting motionless below the stone and those swimming in the open water or crawling above the substrate was noted in intervals of $5 \mathrm{~min}$. The experiments were carried out with the same gammarid combinations and under the same temperature and light regime as described above. In total 40 experiments were conducted. Activity of gammarids was also measured in the absence of a heterospecific. Experimental conditions were as in the mixed-species experiments.

\subsection{Statistics}

A two-way ANOVA served to test whether fish predation rate varied with prey (gammarid) species and substrate in the mixed prey experiments. Tukey's post hoc test was used to detect differences of fish predation rate between different substrates. Additionally, paired ttests were employed to test for differences in predation risk between invasive vs. native gammarids at each substrate. Paired t-tests also served to test whether substrate affinity/activity varied with gammarid species in mixed-species trials. A one-way ANOVA followed by Tukey's post hoc test was employed to test whether fish predation rate varied with prey species in the single prey experiments and whether activity of gammarids varied in single-species experiments.

\section{RESULTS}

\subsection{Mixed prey experiments}

Predation rate of trout varied with prey species and substrate (Tab. 2). The lowest predation rates were always observed in gravelly substrate and high predation rates were observed when either sand or no substrate was present (Tab. 2). In the combinations with $D$. villosus and native gammarids $(G$. roeseli and $G$. fossarum), trout ate many more native gammarids than D. villosus when gravel or stones were used as substrate (Fig. 1; Tab. 3); there was not a single experiment where more native gammarids were eaten than invasives. When sand was used as substrate, the same trends were observed but differences in trout predation rates on gammarids were not significant (cf. Tab. 3). Under no-substrate conditions did trout eat more of the invasive $D$. villosus than the native species. 
Tab. 2. Results of the two-way ANOVA concerning differences in vulnerability to fish predation between different gammarids and on different substrates. Tukey's post hoc shows differences in fish predation rate between different substrates.

\begin{tabular}{|c|c|c|c|c|c|}
\hline \multirow{2}{*}{$\begin{array}{c}\text { Gammarid } \\
\text { combination }\end{array}$} & \multicolumn{2}{|c|}{ Factor species } & \multicolumn{2}{|c|}{ Factor substrate } & \multirow[t]{2}{*}{ Tukey (substrate) } \\
\hline & F & $\mathrm{P}$ & $\mathrm{F}$ & $\mathrm{P}$ & \\
\hline $\mathrm{Dv} v s \mathrm{Gr}$ & 50.3 & 0.0001 & 27.6 & 0.0001 & gravel $v s$ stones, sand, no substrate \\
\hline Dv vs Gf & 20.2 & 0.0001 & 103.3 & 0.0001 & gravel vs stones, sand, $v s$ no substrate \\
\hline Ei vs Gr & 39.4 & 0.0001 & 46.5 & 0.0001 & gravel $v s$ stones, sand, no substrate \\
\hline Ei vs Gf & 11.2 & 0.0013 & 65.7 & 0.0001 & gravel $v s$ stones vs. sand, no substrate \\
\hline
\end{tabular}
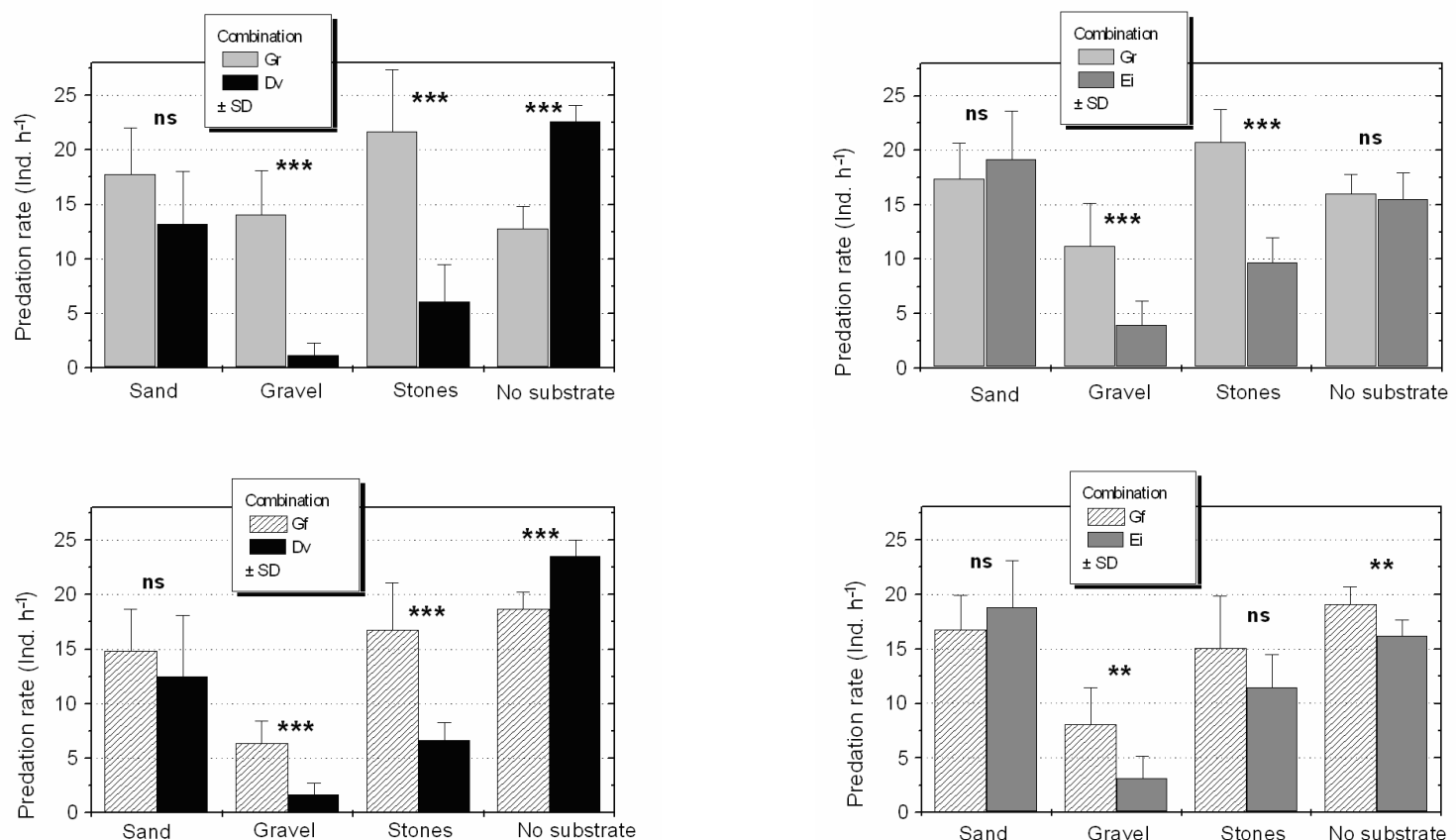

Fig. 1. Mean predation rate of rainbow trout $\pm \mathrm{SD}$ fed on combinations between native and invasive gammarids at different substrates. Asterisks indicate P-levels of the paired t-test (details P levels see table 3). Abbreviations as in table 1.

Tab. 3. Results of the paired $t$-test concerning differences in risk of gammarids to fish predation at different substrates (cf. Fig. 1 and 2). Abbreviations for species as in Tab. $1 ; \mathrm{df}=9$ in all combinations.

\begin{tabular}{lcccc}
\hline Predator & Prey combination & Substrate & $\mathrm{T}$ & $\mathrm{P}$ \\
\hline Trout & Gr $v s$ Dv & sand & 2.2 & $0.058(\mathrm{~ns})$ \\
& gravel & 10.6 & 0.0001 \\
& Gf $v s$ Dv & stone & 9.6 & 0.0001 \\
& no substrate & -10.8 & 0.0001 \\
& sand & 1.2 & 0.24 (ns) \\
& gravel & 8.1 & 0.0001 \\
& Gr $v$ Ei & stones & 7.9 & 0.0001 \\
& no substrate & -6.9 & 0.0001 \\
& sand & -1.5 & 0.18 (ns) \\
& gravel & 5.7 & 0.0001 \\
& stones & 9.1 & 0.0001 \\
& Gf $v s$ Ei & no substrate & 0.54 & 0.60 (ns) \\
& sand & -1.1 & 0.30 (ns) \\
& gravel & 3.7 & 0.005 \\
Perch & stones & 2.1 & 0.07 (ns) \\
& Gp $v s$ Dv & no substrate & 3.9 & 0.004 \\
& Gf $v s$ Dv & stones & 6.8 & 0.0001 \\
& stones & stones & 15.6 & 0.0001 \\
& & & 0.4 & 0001 \\
\hline
\end{tabular}




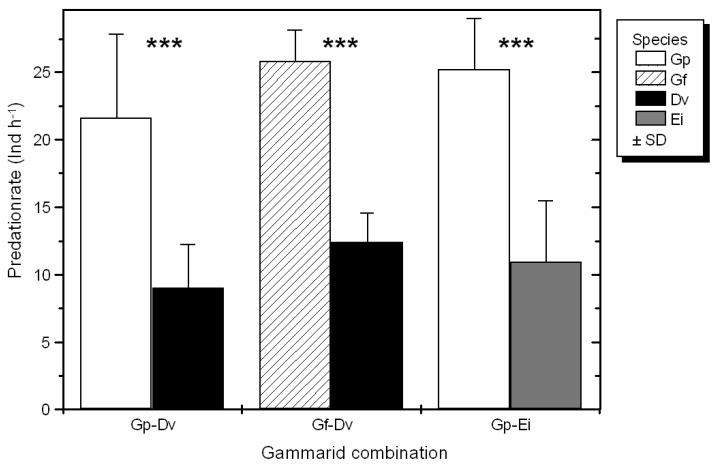

Fig. 2. Mean predation rate of perch \pm SD fed on combinations between native and invasive gammarids at stony substrate. Asterisks mark P-levels of the paired $t$-test (cf. table 3). Abbreviations as in table 1 .
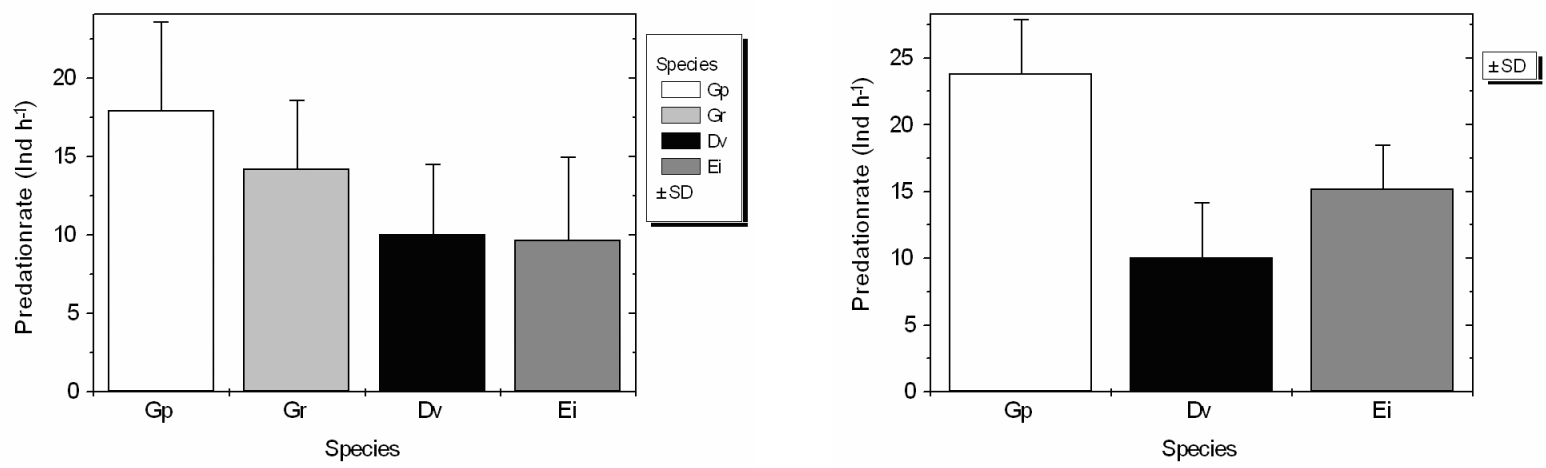

Fig. 3. Mean predation rate of trout (left graph) and perch (right graph) $\pm \mathrm{SD}$ fed on invasive and native gammarids in single-prey experiments. Abbreviations as in table 1.

In the combinations between E. ischnus and $G$. roeseli, many more native gammarids were consumed by trout when gravel or stones were used as substrate (Fig. 1; Tab. 3). When either sand or no substrate was present trout ate the same quantity of $E$. ischnus and $G$. roeseli. In the combination between $E$. ischnus and $G$. fossarum more natives were consumed when gravel was used as substrate. When stones were used as substrate the same trend was observed but difference in predation rate on gammarids were not quite significant (Tab. 3). No difference of trout predation rates on $G$. fossarum and $E$. ischnus was observed when sand was used as substrate (Fig. 1). When no substrate was present trout ate slightly more G. fossarum than E. ischnus.

The experiments with perch as predator and combinations of native and invasive gammarids as prey (which were run with stony substrate only) support the results of the experiments where trout was the predator in that perch also ate many more specimens of native than of invasive gammarids (Fig. 2; Tab. 3).

\subsection{Single prey experiments}

Trout predation rate varied with prey species (ANOVA: $F=6.6(3 / 36) ; P<0.001)$. However, differences of trout predation rates were only significant be- tween G. pulex and both invasive species but not between $G$. roeseli and invasives and not between $G$. pulex and G. roeseli (Tukey's post hoc test). This means that trout ate the same quantity of $G$. roeseli, $D$. villosus and $E$. ischnus, the same quantity of both natives but more G. pulex than D. villosus and E. ischnus (Fig. 3). Perch predation rate also varied with prey species (ANOVA: $\mathrm{F}=$ 26.6(2/27); $\mathrm{P}<0.0001)$. Perch ate more specimens of the native G. pulex than of invasives and more E. ischnus than D. villosus (Tukey's post hoc test).

\subsection{Substrate affinity, activity}

In the mixed-species experiments activity/substrate affinity varied between invasive and native species (Fig. 4; Tab. 4). Native species were more frequently in the open water than invasives which were found attached at the bottom of the stone. This was particularly clear in the combinations between $D$. villosus and native species. Between 0-2 specimens of D. villosus were observed in the open water in the course of the observation period while 7-9 (almost all) G. fossarum and $G$. roeseli were observed swimming freely in the open water. When invasive species were combined (Fig. 5), D. villosus was less active than E. ischnus (Tab. 4). 

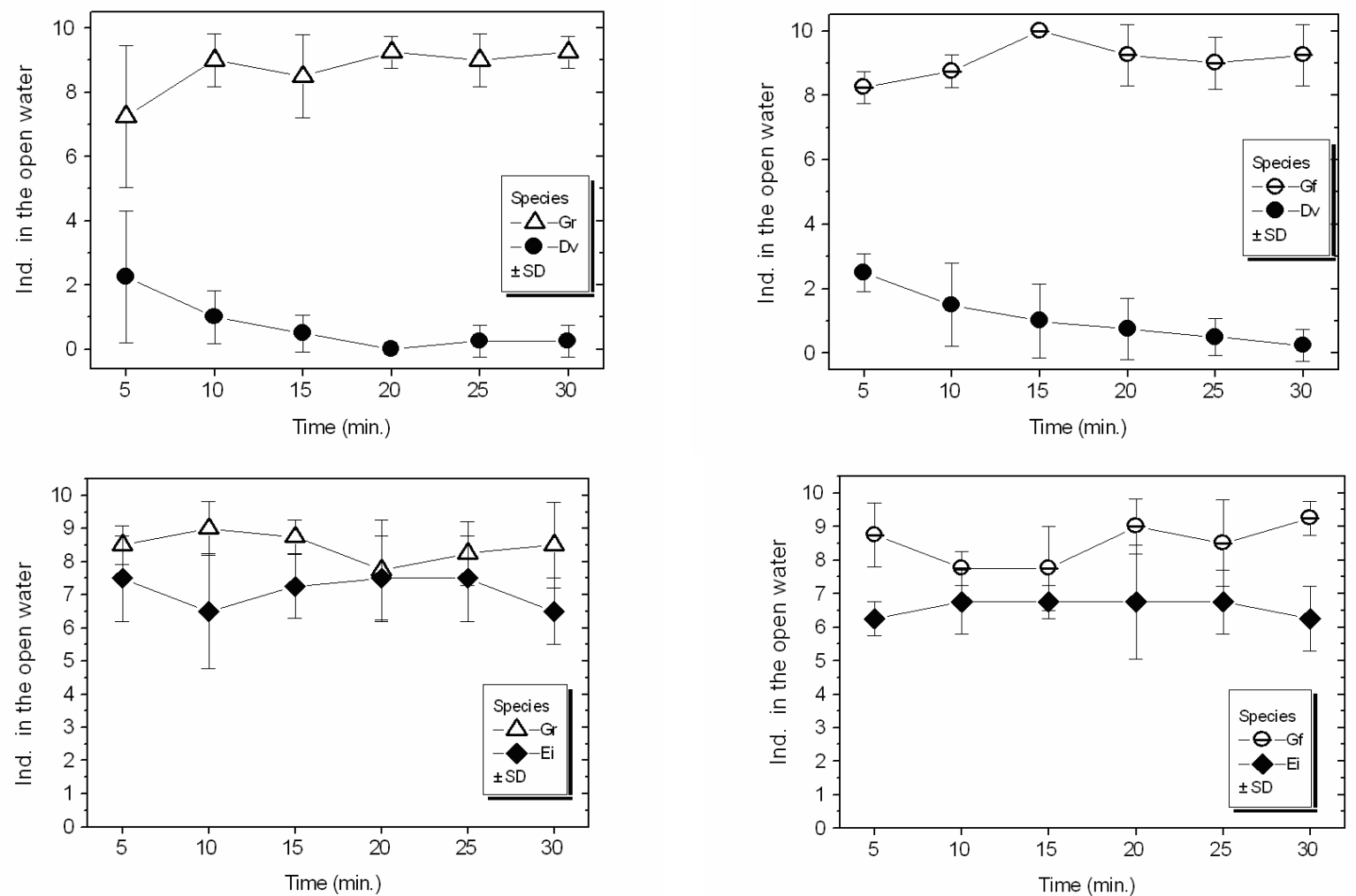

Fig. 4. Gammarids in the open water in combinations between native and invasive gammarids. Means \pm SD during a 30 min. observation period. Abbreviations for different species as in table 1 .

Tab. 4. Results of the paired $t$-test concerning differences in the activity between different gammarid species (cf. Fig. 4 and 5). Abbreviations as in Tab. 1; $\mathrm{df}=23$ in all combinations.

\begin{tabular}{lcc}
\hline Combination & $\mathrm{T}$ & $\mathrm{P}$ \\
\hline Gf $v s$ Dv & 25.1 & 0.0001 \\
Gr $v s$ Dv & 17.3 & 0.0001 \\
Gf $v s$ Ei & 6.5 & 0.0001 \\
Gr $v s$ Ei & 3.6 & 0.002 \\
Dv $v s$ Ei & -9.35 & 0.0001 \\
\hline
\end{tabular}

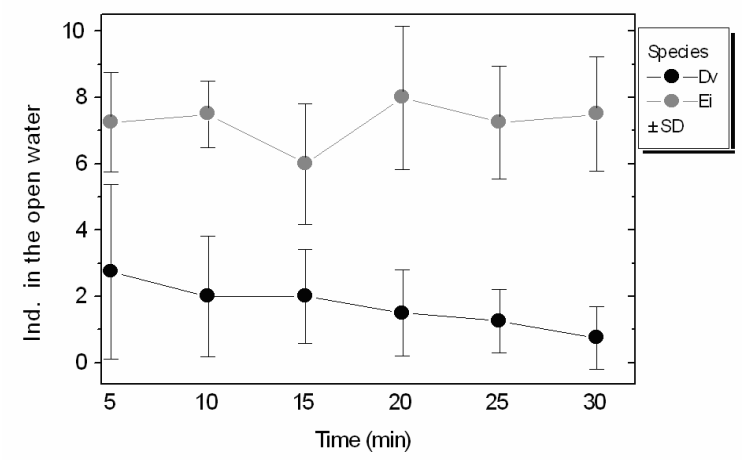

Fig. 5. Gammarids in the open water in combinations between invasive gammarids. Means \pm SD during a 30 min. observation period. Abbreviations for different species as in table 1.
In the single species experiments (Fig. 6) activity also varied with gammarid species (one-way ANOVA: $F=55.5(4 / 116) ; P<0.0001)$. The highest activity was observed for $G$. fossarum, intermediate activities for $G$. roeseli and $E$. ischnus and the lowest activity for $D$. villosus (Tukey's post hoc test).

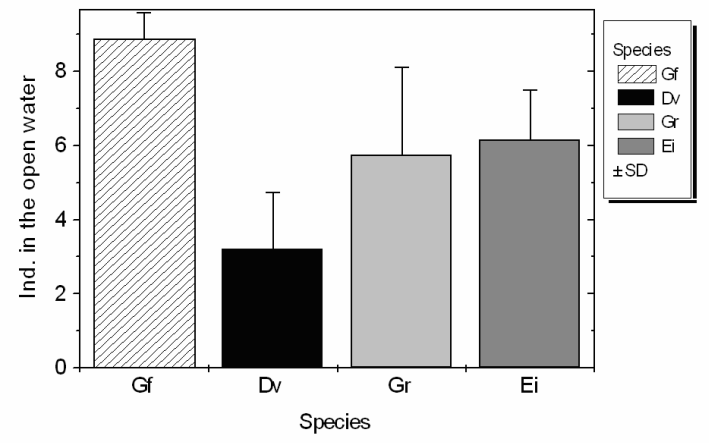

Fig. 6. Gammarids in the open water in single species experiments. Abbreviations for different species as in table 1 .

\section{DISCUSSION}

Predation by fish is an important selective force in freshwaters. Selective predation by fish can shape the structure and composition of freshwater benthic communities (Newman \& Waters 1984). Most fishes 
select large, conspicuous and active prey (Metz 1974; Dahl 1998; MacNeil et al. 1999, 2000). Large size and conspicuous colour increase the visibility of a prey. High activity leads to frequent encounters between predator and prey. Prey either flee or seek refuge when they face a predator. Gammarids seek to hide in the bottom sediments to avoid encounters with fish predators (Williams \& Moore 1982, Hoyle \& Holomuzki 1990; Starry et al. 1998; Wooster 1998).

Our mixed-prey experiments show that fish selected native gammarids over invasives when coarse substrate was present. Between 4-12 times and 2-3 times more native gammarids were consumed than $D$. villosus and E. ischnus, respectively, when gravel was used as substratum, and between 1.5-3 times more native gammarids than invasive ones when stones were employed. This suggests that in rivers where bottom sediments are composed of coarse material which offer refugia for gammarids, native gammarids suffer much higher mortality than D. villosus and E. ischnus due to fish predation. The presence of a refugia has been shown to affect predation risk of gammarids (Harrison et al. 2005). Undoubtedly, the most important factor that lowers predation risk of the invasive gammarids relative to natives is the invasives higher substrate affinity and lower activity. Dikerogammarus villosus, for example, left the substrate only occasionally during our experiments. Native species, by contrast, frequently left the substrate, making them visible and vulnerable to fish attacks.

Although invasive species (at least $D$. villosus) were somewhat larger than natives in our study, and although size may affect handling and ingestion of gammarids by fish (MacNeil et al. 1999), size differences are unlikely to be responsible for the observed selection of natives over invasives by fish in the presence of coarse substrate. Both native and invasive gammarids were eagerly eaten by fish in the absence of shelter. The experiments under no-substrate conditions show that in the absence of shelter the large invader $D$. villosus was eaten even more eagerly than natives. This suggests that larger invasives were as easy to handle as natives and that fish were not gape limited.

Krisp (2003) showed that G. pulex shifted from stony substrates to macrophytes in the presence of $D$. villosus and MacNeil \& Platvoet (in press) showed that the microdistribution of $G$. pulex changed in the presence of the invasive $D$. villosus while there was no effect on the microdistribution of the invader in the presence of the native. Although the native gammarids $G$. pulex, $G$. roeseli are generally more active than $D$. villosus and E. ischnus (Krisp 2003, this study) the results of Krisp (2003) and MacNeil \& Platvoet (in press) suggest some interaction between invaders and natives which could result in an additional increase of natives' activity, and thus increase the risk of being captured by fish.
The results of our single prey experiments show that $G$. pulex was somewhat more frequently eaten by fish than were invasives. In $G$. roeseli the same trends were observed but differences in predation risk between this species and the invasives were not statistically significant. This contrasts to the mixed prey experiments, where all natives were much more heavily preyed upon compared to invasives under coarse substrate conditions. Thus, the results of the single-prey experiments support the suggestion that the presence of invasives could increase predation risk of natives. It is possible that invasives force natives to leave the substrate when refugia are limited.

It is unlikely that predatory interactions between invasive and native species (intraguild predation; e.g. Polis et al. 1989; Dick \& Platvoet 1996) can account for the observed differences in mortality in our experiments since exposure times were too short and we observed no feeding of invasives on natives.

Little to no difference in mortality between native and invasive gammarids under trout predation and a sand substrate, suggests no obvious advantage of invasives concerning their predation risk in rivers where fine substrates prevail. Fine substrate may offer some refuge for gammarids but much less than coarse substrate (Williams \& Moore 1982). Although rivers do not exclusively have either fine or coarse substrate, there are differences in substrate conditions between rivers. Some rivers (such as the Elbe and Oder) have a more sandy substrate while others (such as the Danube and Iller) have a more gravelly substrate.

In summary our experiments show that the invaders $D$. villosus and $E$. ischnus were less frequently eaten by fish in comparison with native gammarids under conditions of coarse substrate in artificial laboratory mixed-prey experiments. Although laboratory conditions do not reflect the complex conditions in nature, our experiments suggest that differences in predation risk between invasives and natives when they co-occur can contribute to the success of the former. Thus our results support the hypothesis that selective predation by fish can be a further reason - besides intraguild predation - for the decline of native gammarids in the presence of invasives.

\section{ACKNOWLEDGMENTS}

We want to thank Interreg III A who supported parts of this study financially. We are grateful to Dick Platvoet (Amsterdam) for the verification of our determinations and to the Dept. Biology III (University of Ulm), in particular E. Kalko, for the permission to use facitities. We further thank two anonymous referees for their valuable comments on an earlier draft of this manuscript.

\section{REFERENCES}

Bisson, P.A. 1978. Diel food selection by two sizes of rainbow trout (Salmo gairdneri) in an experimental stream. J. Fish. Res. Bd Canada, 35: 971-975. 
Byers, J.E. 2000. Differencial susceptibility to hypoxia aids estuarine invasion. Marine Ecology, Progress Series, 203: 123-132.

Byers, J.E. 2002. Physical habitat attribute mediates biotic resistance to non-indigenous species invasion. Oecologia, 130: $146-156$.

Crawley, M.J. 1987. What makes a community invasible? In: Gray A.J., Crawley M.J., Edwards P.J. (Eds), Colonization, succession and stability. Blackwell, Oxford: 429-453.

Dahl, J. 1998. Effects of a benthivorous and a drift-feeding fish on a benthic stream assemblage. Oecologia, 116: 426432.

Dick, J.T.A. 1992. The nature and implications of differential predation between Gammarus pulex and $G$. duebeni celticus (Crustacea: Amphipoda). J. Zool., London, 227: 171-183.

Dick, J.T.A. 1995. The cannibalistic behaviour of two Gammarus species (Crustacea: Amphipoda). J. Zool., London, 236: 697-706.

Dick, J.T.A., I. Montgomery \& R.W. Elwood. 1993. Replacement of the amphipod Gammarus celticus by the introduced $G$. pulex: differential cannibalism and mutual predation. J. Anim. Ecol., 62: 79-88.

Dick, J.T.A. \& D. Platvoet. 2000. Invading predatory crustacean Dikerogammarus villosus eliminates both native and exotic species. Proceedings of the Royal Society of London, Series B, 267: 977-983.

Grabow, K., T.O. Eggers \& A. Martens. 1998. Dikerogammarus villosus SOVINSKY (Crustacea: Amphipoda) in norddeutschen Kanälen und Flüssen. Lauterbornia, 33: 103-107.

Harrison, S.S.C., D.C. Bradley \& I.T. Harris. 2005. Uncoupling strong predator-prey interactions in streams: the role of marginal macrophytes. Oikos, 108: 433-448.

Hoyle, J.D. \& J.R. Holomuzki. 1990. Effect of predatory fish presence on habitat use and diel movement of the stream amphipod, Gammarus minus. Freshwat. Biol., 24: 509-517.

Kinzler, W. \& G. Maier. 2003. Assymetry in mutual predation: possible reason for the replacement of native gammarids by invasives. Arch. Hydrobiol., 157: 473-481.

Kinzelbach, R. 1995. Neozoans in European waters - Exemplifying the worldwide process of invasion and species mixing. Experientia, 51: 526-538.

Kley, A. 2001. Populationsökologie der neozoischen Gammariden Dikerogammarus villosus und Echinogammarus ischnus im Main und Main-Donau-Kanal. Diploma Thesis in Biology, University of Ulm, Germany: $66 \mathrm{pp}$.

Kley, A. \& G. Maier. 2003. Life history characteristics of the invasive freshwater gammarids Dikerogammarus villosus and Echinogammarus ischnus in the river Main and the Main-Donau canal. Arch. Hydrobiol., 156: 457-469.

Krisp, H. 2004. Substratpräferenz, Aktivität, Prädationsneigung und Wachstum von neozoischen und heimischen Gammaridenarten in Laborexperimenten. Diploma Thesis in Biology, University of Ulm: 67 pp.

Lelek, A. 1996. Die allochthonen und die beheimateten Fischarten unserer großen Flüsse - Neozoen der Fischfauna. In: Gebhardt, H., Kinzelbach, R. \& SchmidtFischer S. (Eds), Gebietsfremde Tierarten, Auswirkungen auf einheimische Arten, Lebensgemeinschaften und Biotope. Situationsanalyse. Ecomed Verlag, Landsberg: 197-215.

Lodge, D.M. 1993. Biological invasions: lessons for Ecology. Trends in Ecology and Evolution, 8: 133-137.
Lutz, M. 1997. Gewässerökologische Untersuchungen im Oberlauf der Brenz im Hinblick auf anthropogene Belastungen. Diploma Thesis in Biology, University of Ulm, Germany: 80 pp.

MacNeil, C., R.W. Elwood \& J.T.A. Dick. 1999. Predatorprey interactions between brown trout Salmo trutta and native and introduced amphipods; their implications for fish diets. Ecography, 22: 686-696.

MacNeil, C., R.W. Elwood \& J.T.A. Dick. 2000. Factors influencing the importance of Gammarus spp. (Crustacea: Amphipoda) in the riverine salmonid diets. Arch. Hydrobiol., 149: 87-107.

Metz, J.P. 1974. Die Invertebratendrift an der Oberfläche eines Voralpenflusses und ihre selektive Ausnutzung durch die Regenbogenforelle (Salmo gairdneri). Oecologia, 14: 247-267.

Newman, R.M. \& T.H. Waters. 1984. Size-selective predation on Gammarus pseudolimnaeus by trout and sculpins. Ecology, 65: 1535-1545.

Polis, G.A., C.A. Myers \& R.D. Holt. 1989. The ecology and evolution of intraguild predation. Potential competitors that eat each other. Annual Reviews of Ecology and Systematics, 20: 297-330.

Ricciardi, A., W.W.M. Steiner, R.N. Mack \& D. Simberloff. 2000. Toward a global information system for invasive species. BioScience, 50: 239-244.

Schöll, F. 1996. Erstnachweis von Chaetogammarus ischnus STEBBING im Rhein. Lauterbornia, 5: 71-74.

Schöll, F., C. Becker \& T. Tittizer. 1995. Das Makrozoobenthos des schiffbaren Rheins von Basel bis Emmerich 1986-1995. Lauterbornia, 21: 115-137.

Starry, O., J. Wanzenböck \& D.L. Danielopol. 1998. Tendency of the amphipod Gammarus roeseli GERVAIS to colonize coarse sediment habitats under fish predation pressure. Int. Rev. Hydrobiol., 83: 371-380.

Tittizer, T. 1996. Vorkommen und Ausbreitung aquatischer Neozoen (Makrozoobenthos) in den Bundeswasserstraßen. In: Gebhardt, H., Kinzelbach, R. \& Schmidt-Fischer, S. (Eds), Gebietsfremde Tierarten; Auswirkungen auf einheimische Arten, Lebensgemeinschaften und Biotope Situationsanalyse. Ecomed Verlag, Landsberg: 49-86.

Tittizer, T., F. Schöll, M. Banning \& A. Haybach. 2000. Aquatische Neozoen im Macrozoobenthos der Binnenwasserstraßen Deutschlands. Lauterbornia, 39: 1-73.

Trowbridge, C.D. 1995. Establishment of the green alga, Codium fragile ssp. tomentosoides on New Zealand rocky shores; current distribution and invertebrate grazers. $J$. Ecol., 83: 949-965

Weinzierl, A., S. Potel \& M. Banning. (1996) Obesogammarus obesus (Sars 1894) in der Oberen Donau (Amphipoda, Gammaridae). Lauterbornia, 26: 87-89.

Wells, J.D. \& G. Henderson. 1993. Fire and predation on native and introduced subterranean termites in the laboratory: effect of high soldier number in Coptotermes formosanus. Ecological Entomology, 18: 270-274.

Williams, D.D. \& K.A. Moore. 1982. The effect of environmental factors on the activity of Gammarus pseudolimnaeus (Amphipoda). Hydrobiologia, 96: 137147.

Wooster, D.E. 1998. Amphipod (Gammarus minus) responses to predators and predator impact on amphipod density. Oecologia, 115: 253-259. 